

\title{
KANDUNGAN NIKOTIN DALAM ASAP ROKOK PASIF CIGARET NON FILTER TERKENAL DI INDONESIA
}

\author{
Ikhwan Resmala Sudji ${ }^{1}$ dan Mustanir ${ }^{2}$ \\ ${ }^{1}$ Program Studi Kesehatan Masyarakat STIKes Fort De Kock, Bukittinggi \\ ${ }^{2}$ Jurusan Kimia FMIPA Universitas Syiah Kuala, Banda Aceh \\ 1email : sudji_ir@yahoo.com
}

\begin{abstract}
Passive smoking has higher health risk than active smoking like coronary heart diseases, lung cancer and mortality level. Nicotine is main contain in cigarettes smokes that caused addictive. The nicotine level of the side stream smoke from Indonesia non-filter cigarettes brand $\mathrm{X}$ was analyzed by Gas chromatography-Mass spectrophotometer and Cundiff-Markunas methods for the level of nicotine employing modified smoking standard, namely two puff/min and then were trapping in $\mathrm{HCl} 0.1 \mathrm{~N}$. The total alkaloid result from $13.745 \mathrm{~g}$ burned tobacco (10 cigarettes) was $0.130 \mathrm{~g}$. The nicotine as total alkaloids levels with Cundiff-Markunas methods was $66.860 \%$ and the nicotine level with gas chromatography-mass spectrophotometer was $10.05 \%$.
\end{abstract}

Keywords: nicotine, cigarettes smokes, passive cigarettes smokes. 


\section{DAFTAR PUSTAKA}

1. Church, D. F., and Pryor, W. A., 1985, Free-radical chemistry of cigarette smoke and its toxicological implications, Environ. Health Perspect, 64: 111-126.

2. Kim, H., Liu, X., Kobayashi, T., Conner, H., Kohyama, T., Wen, F., Fang, Q., Abe, S., Bitterman, P., Rennard, S. I., 2004, Reversible cigarette smoke extract-induced DNA damage in human lung fibroblasts, AJRCMB., Articles Published on July 15.

3. Nyunoya, T., Monick, M., Klingelhutz, A., Yarovinsky, T. O., Cagley, J. R., and Hunninghake, G. W., 2006, Cigarette Smoke Induces Cellular Senescence, Am. J. Respir. Cell Mol. Biol., 35(6); 681 - 688.

4. Baglole, C. J., Bushinsky, S. M., Garcia, T. M., Kode, A., Rahman, I., Sime, P. J., and Phipps, R. P., 2006, Differential induction of apoptosis by cigarette smoke extract in primary human lung fibroblast strains: implications for emphysema, Am. $J$. Physiol. Lung. Cell Mol. Physiol., 291(1); L19 - L29.

5. Dube, M. F., and Green, C. R., 1992, Recent Advances in Tobacco Science, Volume 8.

6. Amstrong, B. K., 1984, Merokok dan Kesehatan, Jakarta.

7. Aliunir, N., 1992, Penentuan Kadar Nikotin dalam Berbagai Merk Rokok yang Beredar di Sumatera Barat, Laporan Penelitian, IKIP Padang.
8. Susanna, Dewi, Budi Hartono dan Hendra Fauzan, 2003, Penentuan Kadar Nikotin Dalam Asap Rokok, Jurnal Ekologi Kesehatan, 2 (3): 272-274.

9. Fidrianny, Irda, Supradja, I. G. N. A., Soemardji, A. A., 2004, Analisis Nikotin Dalam Asap Dan Filter Rokok, Acta Pharmaceutica Indonesia, 29(3): 100-104.

10. Nadia, Jones, M., Gabriela Bernardo-Gil, M., Graço Lourenco, M., 2001, Comparison of Methods for Extraction of Tobacco Alkaloids, Journal of AOAC International, 84; 309-316.

11. Pakhale, S. S., and Maru G. B., 1998, Distribution of Mayor and Minor Alkaloids in Tobacco, Mainstream and Sidestream of Smoke of Popular Indian Smoking Products, Food and Chemical Toxicology, 36: 1131-1138.

12. Otsuka, R., H. Watanabe, Hirata, K., Tokai, K., Muro, T., Yoshiyama, M., Takeuchi, K., Yoshikawa, J., 2001, Acute Effects of Passive Smoking on the Coronary Circulation in Healthy Young Adults, JAMA., 286: 436-441.

13. Heidrich, J., Wellmann, J., Heuschmann, P. U., Kraywinkel, K., and Keil, U., 2007, Mortality and morbidity from coronary heart disease attributable to passive smoking, European Heart Journal, 28(20):2498-2502. 
